ANNALS OF “DUNAREA DE JOS” UNIVERSITY OF GALATI
MATHEMATICS, PHYSICS, THEORETICAL MECHANICS
FASCICLE II, YEAR XIII (XLIV) 2021, No. 2
DOI: https://doi.org/10.35219/ann-ugal-math-phys-mec.2021.2.01

\title{
XRF assessment of microcomposition and basicity index of metallurgical slags
}

\author{
Geta Szabo*, Antoaneta Ene \\ 1 “Dunarea de Jos” University of Galati, Faculty of Sciences and Environment, INPOLDE research center, RO \\ 800008 Galati, Romania \\ *Corresponding author: Szabo.Geta@ugal.ro
}

\begin{abstract}
Slag analysis is very important in maintaining the quality standards of metallurgical processes. The chemical structure and the physical features of slag play a very important role in the management of blast furnace (BF) processes, favouring the development of the decreasing reactions and acting as a thermoregulator of the furnace by the adjustment of heat transmission through the metallic bath. In this paper, the following ranges of oxides concentrations were obtained in BF slags by X-ray fluorescence with wavelength dispersion (WXRF): 32.29$35.56 \% \mathrm{SiO}_{2} ; 42.41-44.1 \% \mathrm{CaO} ; 12.20-15.63 \% \mathrm{Al}_{2} \mathrm{O}_{3} ; 0.40-0.85 \% \mathrm{MnO} ; 5.38-6.17 \% \mathrm{MgO} ; 0.45-0.69 \% \mathrm{FeO}$. The calculated basicity index of slags varied between 1.031 and 1.103 , denoting the acidic character of slags.
\end{abstract}

Keywords: XRF technique, slags, blast furnace process, basicity index.

\section{INTRODUCTION}

Blast-furnace (BF) slag is a secondary product that results from the melting of the chemical compounds from the ore barren, coke cinder, the injected coal, and the flux [1-4].

Slag structure is made up of the total amount of the irreducible oxides as well as of different combinations of metals with sulphur. In essence, slag contributes to the removal of sulphur and other elements that damage the pig iron quality. The slag quantity resulted from the pig-iron preparation process varies in wide limits $(280-400 \mathrm{~kg} / \mathrm{t})$, depending on the iron composition of the metallic load, the chemical structure of the sterile, and the specific consumption of coke. Temperature and chemical structure are the main elements that influence slag viscosity [1-3].

$\mathrm{X}$-rays fluorescence (XRF) is an analytical method widely used for the quantitative and qualitative determination of the elementary chemical composition of samples with a variable number of elements. The great advantage of this method of analysis results from the fact that the samples, mainly the metallic ones and the powders, are not destroyed during the analysis and do not require a prior chemical treatment [3-11].

The aim of this paper was to evaluate the microcomposition of blast-furnace slags by XRF along with their basicity index, a parameter that influences the ironmaking industrial process.

\section{METHODOLOGY}

\subsection{X-RAY FLUORESCENCE SPECTROSCOPY}

$\mathrm{X}$-ray fluorescence spectroscopy (XRF) is a technique that can be applied for direct and fast analysis of solid metal samples, thin metal films, petroleum products, cement, coal, and various other 
materials and industrial wastes. XRF is a non-destructive technique, frequently used for analysis performed in the field and for industrial quality control.

An X-ray tube is used to irradiate the sample with a primary beam of X-rays. The primary Xrays are absorbed by the sample elements in a process known as the photoelectric effect. The resulted secondary X-rays (fluorescence) are a characteristic of the element from which they are emitted, like a fingerprint, being independent of the atom's chemical bond. The intensity of the fluorescent radiation is proportional to the concentration of the chemical element in the sample.

The fluorescence X-rays are collimated and directed to an X-ray detector. The energy of each $\mathrm{X}$-ray and the number of X-rays at each energy are recorded. The X-ray intensities (counts) at each energy are compared to values for known standards for quantitative analysis of the unknown specimen, using calibration curves.

Each element is analyzed in optimal conditions using wavelength dispersion of characteristics X-rays (WXRF). For this, a set of parameters was defined (X-ray tube power, collimator, analyzer crystal, detector), depending on the concentration range of the elements, in order to avoid overlap lines $[3,5,6]$. XRF spectral analysis is a surface analysis technique and this is the reason why the surface that will be analyzed must be representative for the entire sample in question. The samples may be solids, liquids, or powders. Samples often require little or no preparation prior to analysis. To remove the mineralogical effect and to diminish the matrix effect that appears in XRF analysis, the molten method is used [3].

The slag samples were collected from different BF charges at UAF of Iron and Steel Works of Galati, Romania, and subjected to various analytical techniques.

\subsection{BLAST-FURNACE SLAG FORMATION}

All oxides that are not reduced during the ironmaking process are found in the slag. These oxides are: oxides of silicium, calcium, aluminium, manganese, magnesium, ferrous oxides - in small quantities - and even vanadium oxides. The proportion of these components depends to a great extent on slag properties [2,3]. Among these, $\mathrm{Si}$ is reduced in a relatively small amount and can be found in pig iron's composition while the other irreducible components are found in the slag's composition in their total amount. Even from the first appearance of slags, from the ore's solid stage until its final touches in the furnace's crucible, their chemical structure changes permanently.

According to the chemical structure and the levels at which slags can be found, specialized literature classifies them as follows [1-3]:

1. Primary slags. In their structure enters an important quantity of ferrous oxides that resulted from the indirect reduction of superior oxides;

2. Intermediary slags. They are characterised by the reduction of the ferrous oxides as a consequence of iron reduction from primary slags and entrance into the $\mathrm{CaO}$ reaction with the formation of calcium silicates that are much more stable than the ferrous silicates;

3. Final slags. Their structure comprises the rest of the irreducible oxides brought either by the metallic charge or by the coke's cinder and the finishing off of the desulphuration reactions.

Slag temperature while evacuating varies between $1450-1550^{\circ} \mathrm{C}$, depending on the thermic regime and chemical structure.

The main features of slags, namely the melting temperature and viscosity, are determined on the basis of the ternary diagrams of the three main constituent oxides: $\mathrm{SiO}_{2}-\mathrm{CaO}-\mathrm{Al}_{2} \mathrm{O}_{3}$. Ternary diagrams may also be used to observe the crystallization manner of slags during cooling [1]. Ternary diagrams are used by the new calculation of the first three main slag components.

Basicity represents the ratio between basic and acid oxides and is expressed through the basicity index $\mathrm{I}_{\mathrm{b}}$, defined by the Equation (1):

$$
\mathrm{I}_{\mathrm{b}}=\frac{(\mathrm{CaO}+\mathrm{MgO}+\mathrm{FeO}+\mathrm{MnO}) \%}{\left(\mathrm{SiO}_{2}+\mathrm{Al}_{2} \mathrm{O}_{3}\right) \%}
$$




\section{RESULTS AND DISCUSSION}

The results obtained by WXRF as average values of five determinations of oxides concentrations in seven slag samples from various BF charges are presented in Figure 1. Based on these results, the basicity index was calculated with the aid of Eq.1 and the values presented in Figure 2 .

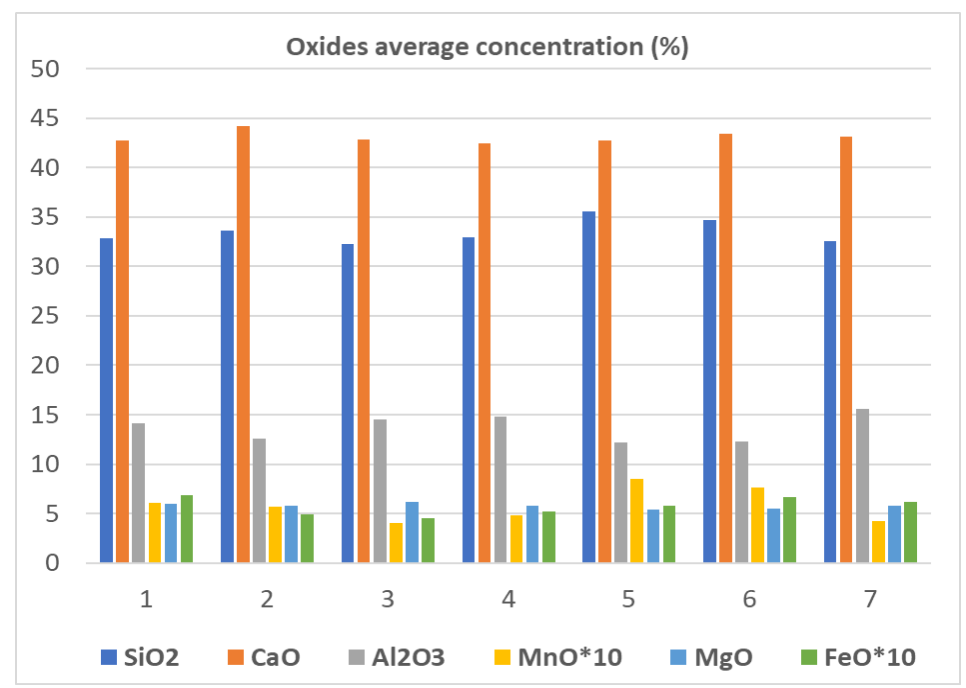

Figure 1. Concentrations of main oxides in BF slags determined by WXRF.

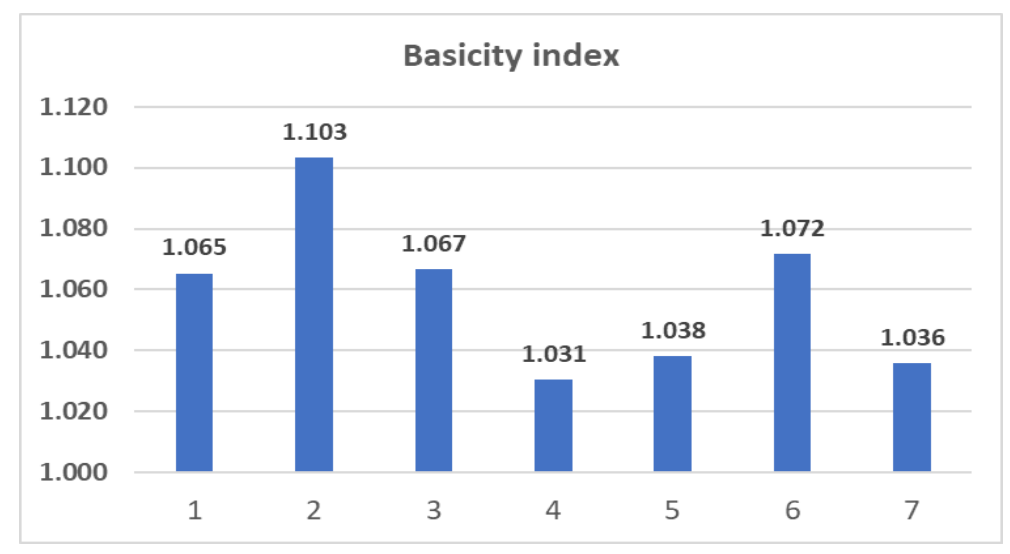

Figure 2. Variation of basicity index $\left(I_{b}\right)$ of investigated BF slags.

The final structure of blast-furnace slags generally varies between the following limits: 30$37 \% \mathrm{SiO}_{2}, 35-50 \% \mathrm{CaO}, 5-20 \% \mathrm{Al}_{2} \mathrm{O}_{3}, 2-8 \% \mathrm{MgO}, 0,5-1,5 \% \mathrm{FeO}$. In this paper we obtained the following ranges of oxides concentrations: $32.29-35.56 \% \mathrm{SiO}_{2} ; 42.41-44.1 \% \mathrm{CaO} ; 12.20-15.63 \%$ $\mathrm{Al}_{2} \mathrm{O}_{3} ; 0.40-0.85 \% \mathrm{MnO} ; 5.38-6.17 \% \mathrm{MgO} ; 0.45-0.69 \% \mathrm{FeO}$ (Figure 1).

Slags in which basic oxides are predominant, where $\mathrm{I}_{b}=1.20 \div 1.30$, are named basic slags and provide a high quality desulphuration. Acid slags with $\mathrm{I}_{\mathrm{b}}=1.00 \div 1.15$ are thick and contain larger quantities of $\mathrm{FeO}$ than the basic ones. When the furnace temperature increases, the process of silicium reduction by its pig-iron growth determines the decrease of $\mathrm{SiO}_{2}$ from the slag's structure and will increase the basicity index. When the furnace gets cold, the degree of Si reduction decreases and the slag will have a greater quantity of $\mathrm{SiO}_{2}$ becoming more acid. In pig-iron, the amount of $\mathrm{S}$ increases. At a cold running of the furnace, slags in the breach are coloured in brown to black, because of the incomplete reduction processes of $\mathrm{Fe}$ and $\mathrm{Mn}$ oxides, that pass in slag in great amounts under the form of $\mathrm{FeO}$ and $\mathrm{MnO}$. 
Our results demonstrated an acidic character of all the slag samples, the basicity index varying between 1.031 and 1.103 (Figure 2). This parameter is very important for conducting the iron manufacture process in the blast furnace and correcting the proportions of raw and auxiliary materials used for the elaboration of pig iron.

\section{CONCLUSIONS}

X-ray fluorescence with wavelength dispersion (WXRF) is a fast and accurate method used for the quantitative and qualitative determination of the elementary chemical composition of industrial samples with a variable number of elements. The great advantage of this method results from the fact that the samples are not destroyed during the analysis and do not require prior chemical treatment.

The chemical structure and the physical features of slag play a very important role in the management of furnace processes, favouring the development of decreased reactions and acting as a thermoregulatorof the furnace by adjusting heat transmission through the metallic bath.

WXRF allowed the determination of concentrations variability of the main oxides in several slags during ironmaking and the estimation of the basicity index, parameters whose knowledge is important for taking appropriate measures for conducting metallurgical processes and choosing correct quantities of raw and auxiliary materials (iron ores, coke, fluxes, etc.) in the charge mixture.

Acknowledgments: This research was funded by internal grant no. RF 3621/2021 of "Dunarea de Jos" University of Galati, Romania. The authors are thankful to eng. phys. Janet Gradinaru from Iron and Steel Works of Galati for the help in processing the analytical data.

\section{References}

1. Gâdea S., Rău A., Oprea F., Tripşa I., Geru N., Manualul inginerului metalurg (Metallurgical engineer's manual), vol. I, Editura Tehnica, Bucharest, 1978.

2. Ene A., Studiul structurii de microelemente a minereurilor de fier, aglomeratelor şi produselor siderurgice corelate prin metode atomice şi nucleare (Study of the microelement structure of iron ores, agglomerates and correlated iron and steel products by atomic and nuclear methods), Doctoral thesis, University of Bucharest, Faculty of Physics, 1997.

3. Gîlcanu (Szabo) G., Aplicaţii ale fluorescenţei de raze $X$ în studiul probelor industriale şi de mediu (Applications of X-ray fluorescence in the study of industrial and environmental samples), Doctoral thesis, University of Bucharest, Faculty of Physics, 2014.

4. Ene A., Tehnici radiometrice de analiză și control (Radiometric techniques of analysis and control; in Romanian), Dunarea de Jos University Foundation Publishing House, Galati, 2006.

5. Ene A., Applications of high sensitivity analytical techniques in industry and pollution management for trace chemical composition characterization of complex samples, Habilitation thesis, Dunarea de Jos University of Galati, 2015.

6. Ene A., Gheorghies C., Frontasyeva M. V., X-ray based techniques used in materials analysis and control, The 17th International conference Tehnomus XVII, 17-18 May 2013, Suceava, Romania, Tehnomus Journal NEW TECHNOLOGIES AND PRODUCTS IN MACHINE MANUFACTURING TECHNOLOGIES, Year 2013 (1) (2013) 193-196.

7. Ene, A., Pantelica, A, Study of transfer of minor elements during ironmaking by neutron activation analysis, Radiochimica Acta, 98 (1) (2010) 53-57, DOI: 10.1524/ract.2010.1685.

8. Ene, A., Pantelica A., Freitas M.C., Bosneaga A., EDXRF and INAA analysis of soils in the vicinity of a metallurgical plant, Rom. Journal Phys. 56 (7-8) (2011) 993-1000.

9. Ene A, Sloata F. XRF analysis of arsenic and selected metals in contaminated sand from the dismantling of industrial distillation plants, Journal of Science and Arts, Year 20, No. 4(53) (2020) 1011-1018.

10. Ene A., Moraru L., Dănilă E., Cioară L., Study of characteristic X-ray spectra induced in complex matrices by radioisotope and electron excitation, Annals of the University Dunarea de Jos of Galati, Fascicle II Mathematics, Physics, Theoretical Mechanics, YEAR V(XXXVI) (2013) 40-43.

11. Sloata F., Ene A., Optimization of X-ray fluorescence technique for the analysis of heavy metals contained in wastes from the electrical and electronic equipment industry, Annals Dunarea de Jos Univ. Galati, Fasc. II. Mathematics, Physics, Theoretical Mechanics, Year X(XLI) (2018) 111-117. 